\title{
DIAGNOSTICS OF TRACK QUALITY OF BALLASTLESS TRACK AND TRANSITION AREAS IN VICINITY OF PORTALS OF TUNNEL TURECKY VRCH
}

\author{
Michal ŠMALO',* \\ ${ }^{1}$ Department of Railway Engineering and Track Management, Faculty of Civil Engineering, University \\ of Żilina, Univerzitná 1, 01026 Žilina, Slovakia. \\ corresponding author: michal.smalo@fstav.uniza.sk.
}

\section{Abstract}

The paper deals with the partial results of diagnostics of experimental sections of ballastless track Rheda $2000 \AA$ and transition areas between ballastless and ballasted track structure around portals of tunnel Turecky vrch after six measurement cycles. The paper presents differences between each operational measurement and the measurement before putting sections into operation, which indicates a development of track geometry quality.
\end{abstract}

\section{Keywords:}

Railway track; Ballasted track; Ballastless track; Slab track;

Track geometry.

\section{Introduction}

A ballasted track is marked such railway track where track skeleton is located in the gravel ballast. In the case of high service and axle load and introducing higher speeds there are proved limits of ballasted track structure, particularly in its ability to guarantee the long-term moving of rail vehicles operationally safe, reliable and easy-to-maintain track [1].

The ballasted track is characterized by "floating" placement of track skeleton, which causes the growth of dynamic forces during each passage of a rail vehicle or train that cause gradual degradation of track geometry. This phenomenon increases with increasing track speeds and thus increases the cost of maintaining and share of closure of traffic tracks, which reduce the attractiveness of rail infrastructure for its users. It is sufficient, however, if in construction there is only replaced the weakest element of standard railway superstructure in the track, and this is the ballast, with other more appropriate component which does not show particular plastic behaviour. Such substitute is a structure, where the track skeleton is monolithic structure or fixed on a concrete or asphalt supporting layer (layered structure); structural solution, which is referred to as unconventional railway superstructure. This concept of track is currently referred to as a ballastless track, in which the required flexibility of the superstructure for the system wheel / rail is secured using elastic elements disposed between a rail and rail support or under a rail support. The term ballastless track represents the structure of railway superstructure, in which a spread function of railway ballast is replaced by reinforced materials, and which is placed on a concrete or asphalt supporting slab. The term ballastless track is also often replaced by the term slab track.

\section{Description of experimental sections}

Monitored experimental sections are situated on modernized double-track railway line Nove Mesto nad Vahom - Puchov and are located in areas of southern and northern portal of the tunnel Turecky vrch. The track speed in both tracks is $160 \mathrm{~km} \cdot \mathrm{h}^{-1}$, which ranks the railway line to the category of velocity zone No. 4 (RP4) [2].

Modernisation of track Nove Mesto nad Vahom - Puchov section 24-32-01 Nove Mesto nad Vahom - Trencianske Bohuslavice started in September 2009 and was completed in May 2013. The railway tunnel, which is part of the track section, is the first tunnel in Slovakia, which is designed and implemented according to the technical specifications for interoperability for conventional tracks, it corresponds to the latest trends in tunnel and railway construction and should become a model for all future tunnels that will be built in Slovakia within the modernization of railway tracks. Double-track tunnel is designed to structure gauge of UIC C with axial distance of tracks $4200 \mathrm{~mm}$ [3]. The total 
length of the tunnel Turecky vrch in the axis is $1775 \mathrm{~m}$. Tunnel tube of the section excavated has a length of $1738.5 \mathrm{~m}$ and is followed by excavated sections of the south portal of length $25 \mathrm{~m}$ and the north portal in the length of $10 \mathrm{~m}$. The entire length, including the portal sections, includes integrated cross-section of double-track tunnel of net tunnel cross section of $6.1 \mathrm{~m}$, there are just two chambers for stretching traction supply with extended cross-section in the middle of the tunnel. Double-track in the tunnel is designed for the speed of $200 \mathrm{~km} / \mathrm{h}$ with curves of a radius of $2000 \mathrm{~m} \mathrm{[1]}$.

The structure of ballastless track was designed, as already mentioned, due to the reduction of the area of cutting and also durability and fixation of the track position and its minimum maintenance during the operation. The structure of ballastless track of Rheda $2000^{\circledR}$ system passes through different types of track subgrade. It begins in the south portal and passes through the entire tunnel. Then, the ballastless track structure continues on bridges and earthwork behind the north portal. The structure of ballastless track itself also includes transition areas on both ends, which ensure smooth transition (smooth change of stiffness) of rigid structure of ballastless track, whose total length is 2 $280.145 \mathrm{~m}$ (it starts in new km 102.459825 and ends in new km 104.740 000), where its particular parts are: transition area $-45.175 \mathrm{~m}$, tunnel $-1775.000 \mathrm{~m}$, bridges $-34.770 \mathrm{~m}$ and earthwork $425.200 \mathrm{~m}$ [4].

The structure of ballastless track Rheda $2000^{\boxplus}$ system is has been verified by years of operation on the German railways. Due to the complex directional conditions and bridges located immediately behind the north portal, the structure of ballastless track is established not only in the tunnel itself, but it almost continues to the railway station Trencianske Bohuslavice on the north side of the tunnel. Total length of the ballastless track structure is up to $4480 \mathrm{~m}$ [5]. Due to the diversity of subgrade stiffness (tunnel bottom, bridge and railway substructure on the earthwork), the system of the ballastless track structure is modified, which is reflected in the thickness of concrete structure and also in its reinforcement [3].

The structure of ballastless track Rheda $2000 \AA$ system is made up of its own monolithic structure of ballastless track, which is divided in its track section in question into 3 basic types [1]:

- in tunnel: monolithic reinforced concrete slab of variable thickness (according to track elevation) concrete class C 35/45 with concreted twin-block sleepers, lying on the concreted bottom of the tunnel tube (anchored with the underlying slab of the tunnel bottom in the place near portals (Fig. 1),

- on earthwork: monolithic reinforced concrete slab of constant thickness $240 \mathrm{~mm}$ - concrete class C $35 / 45$ with concreted twin-block sleepers (also called TCL), lying on a monolithic slab of plain concrete class C 12/15 of constant thickness of $300 \mathrm{~mm}$ (also called HBL). Track cant in curves consists of slope of substructure. There is a TCL slab anchored to HBL slab in the place between the northern portal of the tunnel and bridge over the brook Bosacka,

- on bridges: monolithic reinforced concrete slab of variable thickness (according to track elevation) concrete class C 35/45 with concreted twin-block sleepers, lying on the separation layer Styrodur + foil on the construction of the bridge (Fig. 2).

Rails used in the system of the ballastless track are the same as in the case of ballasted track, and the shape of $60 \mathrm{E} 2$, welded into continuous welded rail track. The rails are fastened to the structure of ballastless track using the system Vossloh 300-1U. It is indirect elastic rail fastening, similar to the normal rails on railway sleeper. Standard distribution of double-block sleepers, which were concreted in monolithic slab, has a value of $650 \mathrm{~mm}$. This value was adjusted as necessary (reduced) only on bridges and areas where the location of dilatation cracks in the inter sleeper spaces is needed. Double-block sleepers are a type of B 355.3 U60M of manufacturer ZPSV a.s. The transition of the structure of ballastless track to ballasted track consists of reinforced concrete tubs of length of $20 \mathrm{~m}$, filled with ballast of variable thickness below the bottom edge of the sleeper BP-3 (250 - $350 \mathrm{~mm}$ ), lined with elastic pad. The space between the tracks in the tunnel and the bridge consists of infill concretes; outside side of the structure of ballastless track on earthwork is filled up with ballast of fraction $31.5 / 63 \mathrm{~mm}[1]$. 


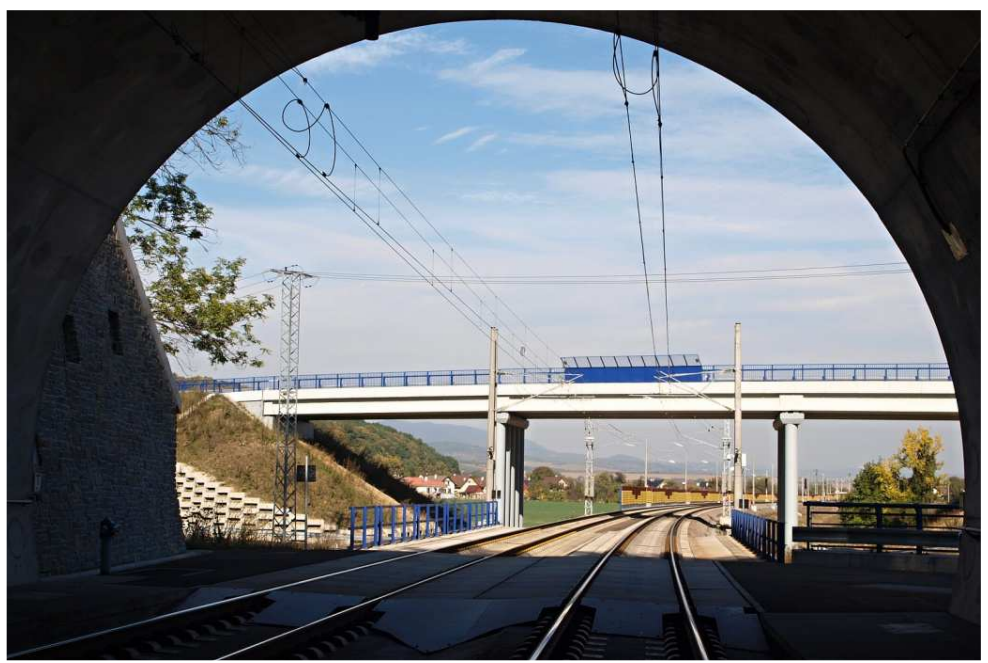

Fig. 1: Ballastless track structure in the area of northern portal.

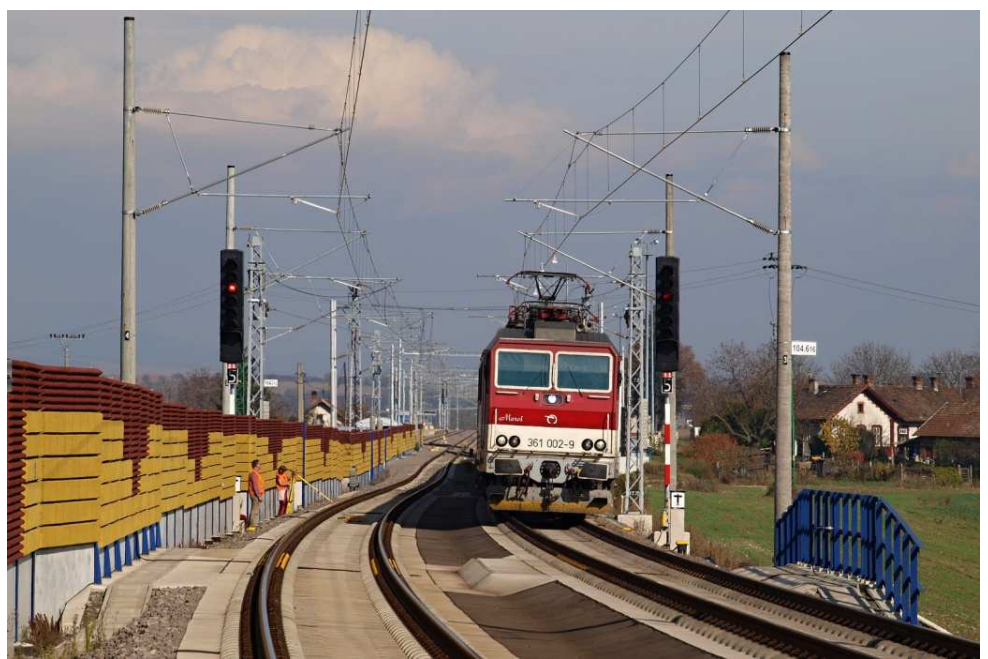

Fig. 2: Ballastless track structure on the earthwork and on the bridge (area of northern portal).

The critical place of the ballastless track structure is transition area between ballasted and ballastless track. In terms of dynamic effects it is a place with a change in stiffness and thus there was paid a special attention to this place. There was used a new type of transition area using standard components of railway superstructure, while without the need for stabilization of the superstructure within the transition area of bonding. The structure consists of reinforced concrete tub of concrete C 30/37 of length $20 \mathrm{~m}$. Thickness of ballast under the sleepers decreases in the direction to the structure of ballastless track, thus stiffness of the subgrade gradually increases. The bottom and walls are lined with elastic mat, whose task is to simulate the deformation properties of the soil of earthwork. There is water and moisture isolation below the elastic mat (Fig. 3). 


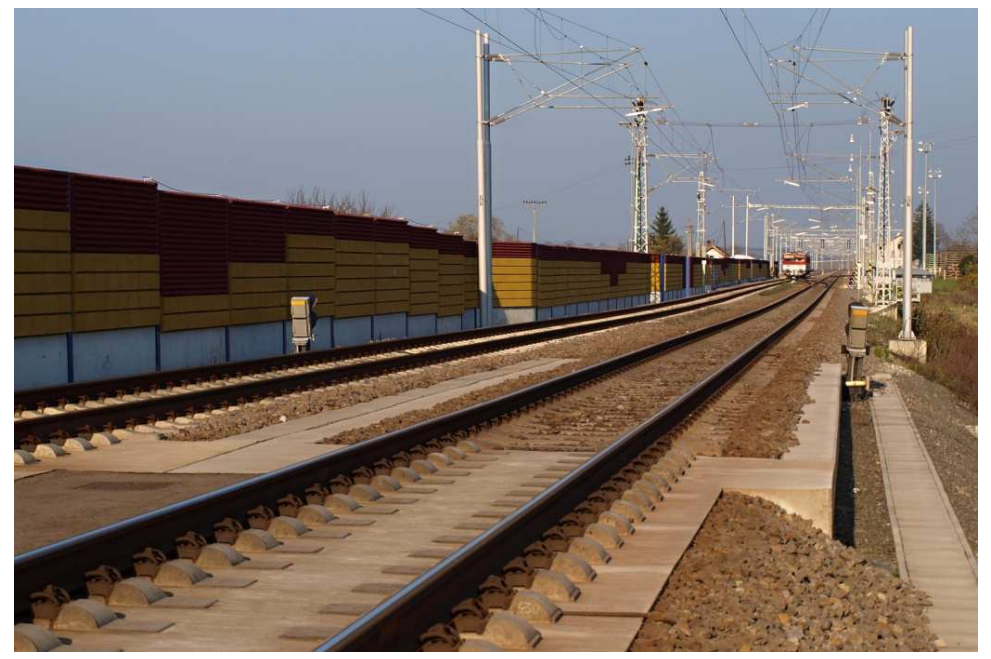

Fig. 3: Transition area between ballastless and ballasted track (area of northern portal).

\section{Diagnostics of relative track alignment design and track geometry of experimental sections around portals of tunnel Turecky vrch}

The experimental track sections are marked as [2]:

- section 1.1 (track No. 1, south portal of the tunnel Turecky vrch) and 2.1 (track No. 2, south portal; both sectors of length $175 \mathrm{~m} ; \mathrm{km} 102.360000-\mathrm{km} 102.535000)$ :

- km 102.360000 - km 102.460500 ballasted track,

- km $102.460500-\mathrm{km} 102.480500$ transition area,

- km 102.480500 - km 102.535000 ballastless track.

- section 1.2 (track No. 1, north portal of the tunnel Turecky vrch) and 2.2 (track No. 2, north portal); both sectors of length $640 \mathrm{~m} ; \mathrm{km} 104.200000-\mathrm{km} 104.840$ 000):

- km 104.200000 - km 104.720500 ballasted track,

- km 104.720500 - km 102.480500 transition area,

- km 104.740500 - km 104.840000 ballastless track.

Diagnostics of relative track alignment design and track geometry of the track section was implemented seven times so far - immediately before putting line tracks into operation and every six months in spring and autumn.

Diagnostics of structure layout and track geometry of the track section [2]:

- measurement before putting sections into operation (MSO) 10.-11.7.2012 and 2.- 3.10.2012,

- the first operational measurement (PO1) 9.-10.4.2013, 21.- 22.4.2013,

- the second operational measurement (PO2) 8.-09.10.2013, 21.-22.10.2013,

- the third operational measurement (PO3) 25.5.2014 and 28.5.2014,

- the fourth operational measurement (PO4) 29.10.2014,

- the fifth operational measurement (PO5) 25.3.2015 and 17.4.2015,

- the sixth operational measurement (PO6) 14.-15.10.2015.

Evaluation of parameters assessed according to valid technical standards and regulations:

- Geometrical Position and Arrangement of 1435 mm Gauge Railways, SÚTN Bratislava, 1999 and Amendment 1, SÚTN Bratislava, 2002 for railway tracks of track speeds of $160 \mathrm{~km} \cdot \mathrm{h}^{-1}<\mathrm{V} \leq 200 \mathrm{~km} \cdot \mathrm{h}^{-1}$ (RP4) [6],

- ZSR SR 103-7 (S) Measurement and Evaluation of Track Geometry by Measuring Trolley KRAB (in Slovak), GR ZSR, 2008 [7].

Diagnostics of track alignment design and track geometry is carried out by continuously measuring trolley $K R A B^{T M}$-Light (Fig. 4). The measurement is referred to as continuous, but in fact, the data is recorded with the measuring step of $250 \mathrm{~mm}$ [8]:

- gauge deviation $R K$ (after calculating is also recorded change of gauge $Z R$ ),

- alignment of right rail string $S R$ (after calculating is also recorded alignment of left rail string $S L$ ),

- rail top level of right rail string $V R$ (after calculating is also recorded rail top level of left rail string $V L)$,

- cant $P K$, 
- quasi-twist on a short base (calculating to a quasi-twist on a base of $1.8 \mathrm{~m}$ long $-Z K 1.8$, on a base of $6.0 \mathrm{~m}$ long $-Z K 6.0$ and on a base of $12.0 \mathrm{~m}$ long $-Z K$ 12.0),

- track distance.

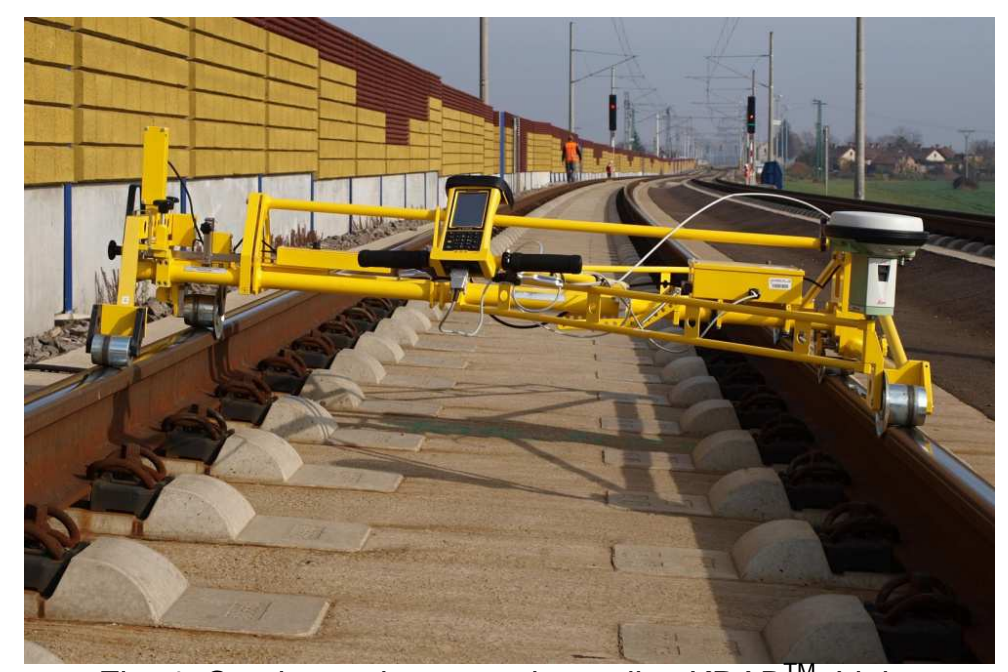

Fig. 4: Continuously measuring trolley $\mathrm{KRAB}^{\mathrm{TM}}$-Light.

Measured parameters were evaluated according to limit input deviations for acceptance of works with use of new material (MSO) and according to operational deviations and limit operational deviations (PO1, PO2, PO3 and PO4) (Table 1).

Table 1: The deviations of the relative geometric parameters of the track for RP4 [6].

\begin{tabular}{|c|c|c|c|c|c|c|c|}
\hline Measured parameter & \multicolumn{2}{|c|}{$\begin{array}{l}\text { Limit input } \\
\text { deviations }\end{array}$} & \multicolumn{2}{|c|}{$\begin{array}{l}\text { Operational } \\
\text { deviations }\end{array}$} & \multicolumn{2}{|c|}{$\begin{array}{l}\text { Limit operational } \\
\text { deviations }\end{array}$} & \multirow{2}{*}{$\begin{array}{c}\text { Note } \\
-\end{array}$} \\
\hline $\mathrm{RK}(\mathrm{mm})$ & -2 & 2 & -3 & 5 & -5 & 10 & \\
\hline $\mathrm{ZR}(\mathrm{mm} / \mathrm{m})$ & \multicolumn{2}{|c|}{2} & \multicolumn{2}{|c|}{3} & \multicolumn{2}{|c|}{4} & - \\
\hline $\mathrm{PK}(\mathrm{mm})$ & -3 & 3 & -6 & 6 & -8 & 8 & - \\
\hline Measured parameter & \multicolumn{2}{|c|}{ Limit value } & \multicolumn{2}{|c|}{ Operational value } & \multicolumn{2}{|c|}{$\begin{array}{l}\text { Limit operational } \\
\text { value }\end{array}$} & Note \\
\hline \multirow{3}{*}{$\begin{array}{l}\text { ZK (1:n) } \\
\text { (mm / base) }\end{array}$} & \multicolumn{2}{|c|}{$\begin{array}{c}1: 250 \\
(7.2 ; 4.0)\end{array}$} & \multicolumn{2}{|c|}{$\begin{array}{c}1: 250 \\
(7.2 ; 4.0)\end{array}$} & \multicolumn{2}{|c|}{$\begin{array}{c}1: 167 \\
(10.8 ; 5.99) \\
\end{array}$} & $\begin{array}{c}\text { on measuring base } \\
1.8 \mathrm{~m}\end{array}$ \\
\hline & \multicolumn{2}{|c|}{$\begin{array}{c}1: 832 \\
(7.2 ; 1.20)\end{array}$} & \multicolumn{2}{|c|}{ not evaluated } & \multicolumn{2}{|c|}{$\begin{array}{c}1: 250 \\
(24.0 ; 4.0)\end{array}$} & $\begin{array}{l}\text { on measuring base } \\
6.0 \mathrm{~m}\end{array}$ \\
\hline & \multicolumn{2}{|c|}{ not evaluated } & \multicolumn{2}{|c|}{ not evaluated } & \multicolumn{2}{|c|}{$\begin{array}{c}1: 333 \\
(36.0 ; 3.0)\end{array}$} & $\begin{array}{c}\text { on measuring base } \\
12.0 \mathrm{~m}\end{array}$ \\
\hline Measured parameter & \multicolumn{2}{|c|}{$\begin{array}{l}\text { Limit input relative } \\
\text { deviations }\end{array}$} & \multicolumn{2}{|c|}{$\begin{array}{c}\text { Relative } \\
\text { operational } \\
\text { deviations }\end{array}$} & \multicolumn{2}{|c|}{$\begin{array}{l}\text { Limit operational } \\
\text { relative deviations }\end{array}$} & Note \\
\hline VL, VP (mm) & -3 & 3 & -6 & 6 & -8 & 8 & - \\
\hline $\mathrm{SL}, \mathrm{SP}(\mathrm{mm})$ & -3 & 3 & -6 & 6 & -8 & 8 & - \\
\hline
\end{tabular}

Each of the sections No. 1.1 and No. 2.1 is represented by 701 samples, each of the sections No. 1.2 and No. 2.2 is represented by 2561 samples for the diagnostics [2].

\section{Assessment of results of track alignment design and track geometry diagnostics}

There are presented only partial result of evaluation of track quality of ballastless track and transition areas in vicinity of portals of tunnel Turecky vrch focused on comparison of differences of gauge deviation $(\triangle \mathrm{RK})$ and cant $\mathrm{PK}$. The results of measurement before putting sections into operation (MSO) has been compared to operational measurements (PO1, PO2, PO3, PO4, PO5 and PO6) and maximal / minimal differences of gauge deviation ( $\triangle \mathrm{RK})$ are shown in Fig. 5 and maximal / minimal differences of cant PK are shown in Fig. 6 [9], [10], [11]. 
Measured parameters were evaluated according to limit input deviations for acceptance of works with use of new material (MSO) and according to operational deviations and limit operational deviations (PO1, PO2, PO3, PO4, PO5 and PO6) in Table 1 [9], [10], [11].

Progress of gauge deviation $(\Delta R K)$ and cant $P K$ - differences between measurement before putting section into operation and operational measurements in each track and each section is shown in Fig. 7 to Fig. 14.

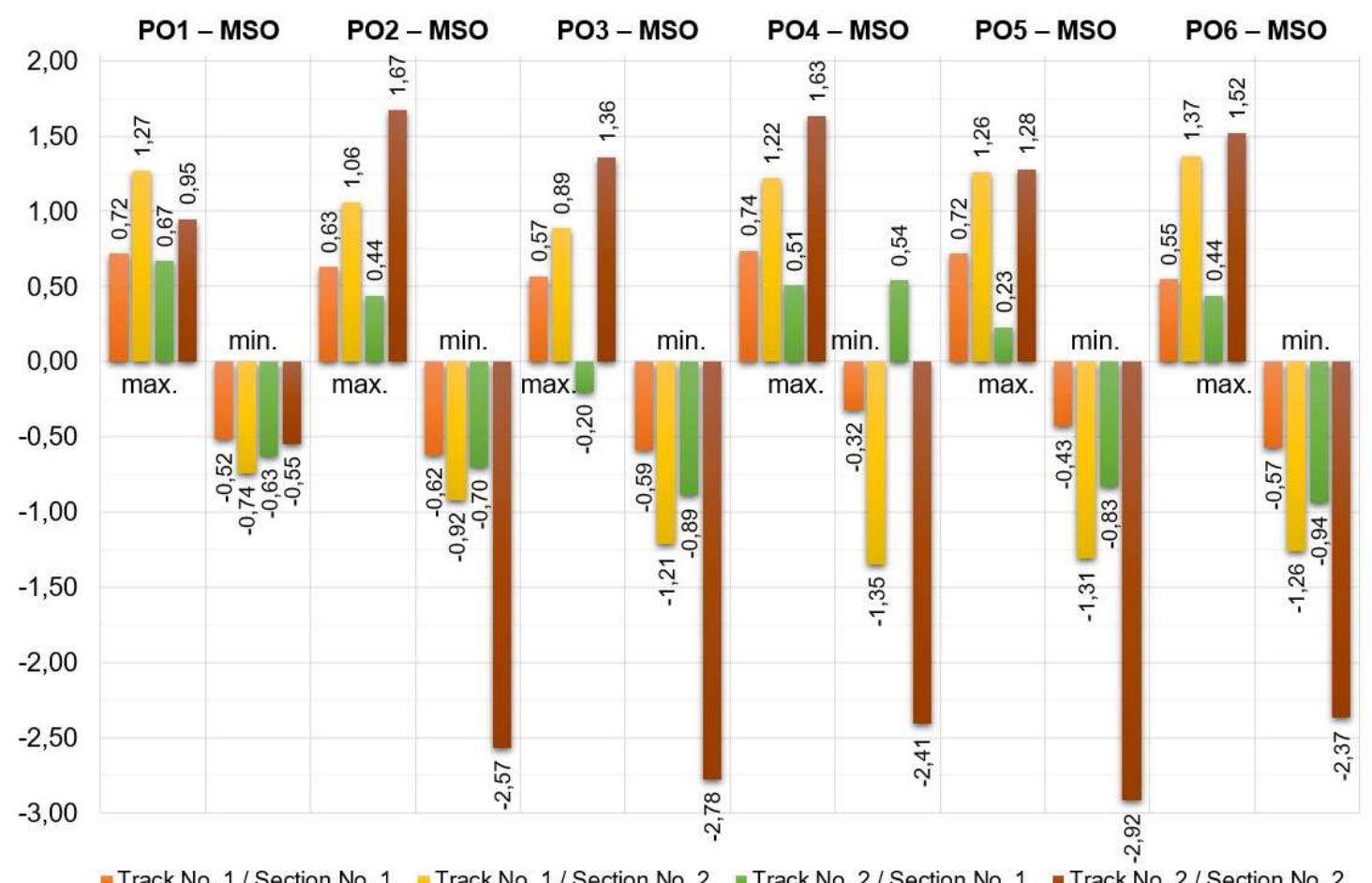

Fig. 5: Differences of measurement of $\triangle R K$ - operational measurement (PO1, PO2, PO3, PO4, PO5, $\mathrm{PO6}$ ) and measurement before putting sections into operation (MSO).

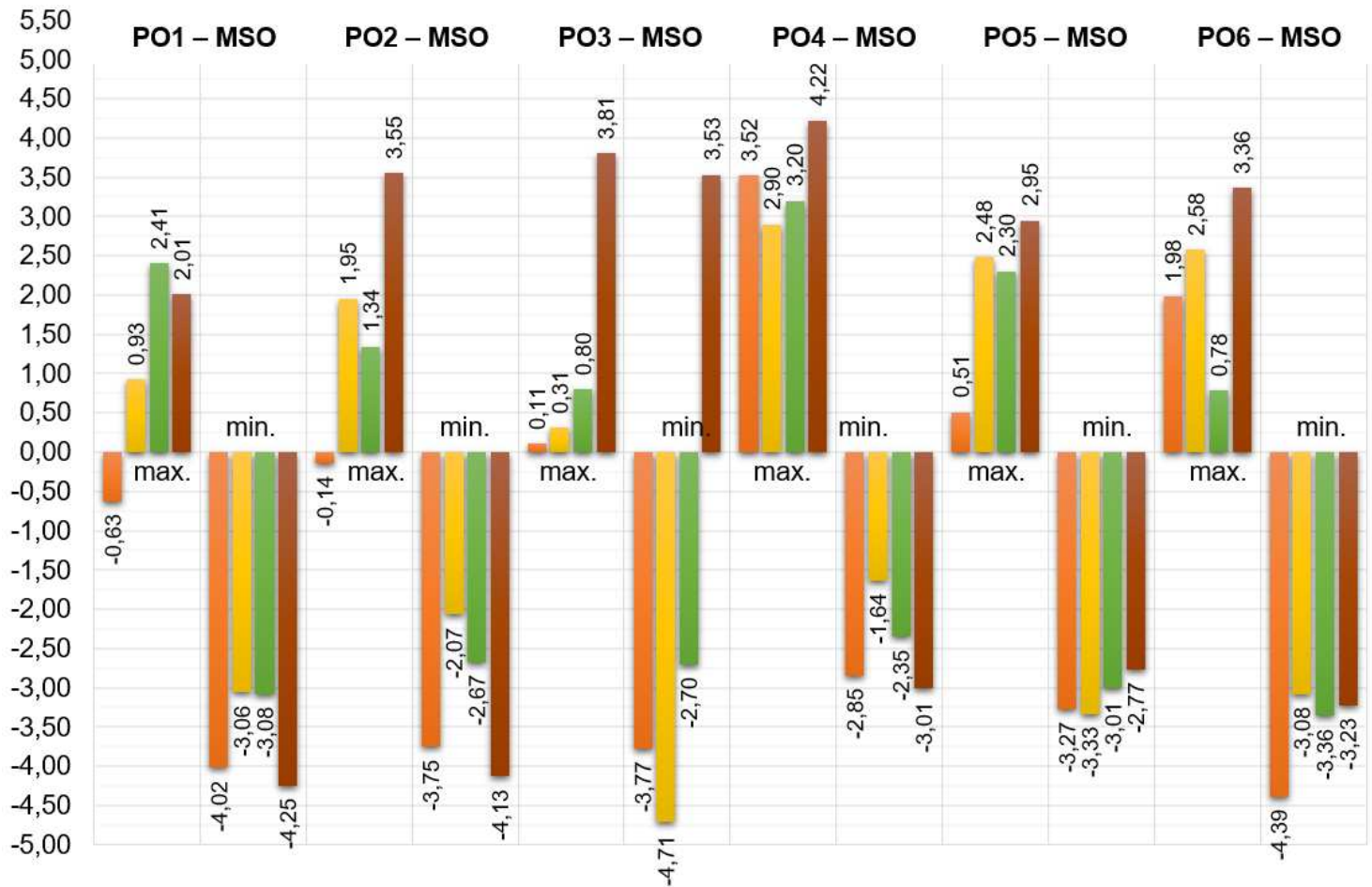

$=$ Track No. 1 / Section No. $1=$ Track No. 1 / Section No. 2 Track No. 2 / Section No. 1 mrack No. 2 / Section No. 2

Fig. 6: Differences of measurement of PK - operational measurement (PO1, PO2, PO3, PO4, PO5, $\mathrm{PO6}$ ) and measurement before putting sections into operation (MSO). 


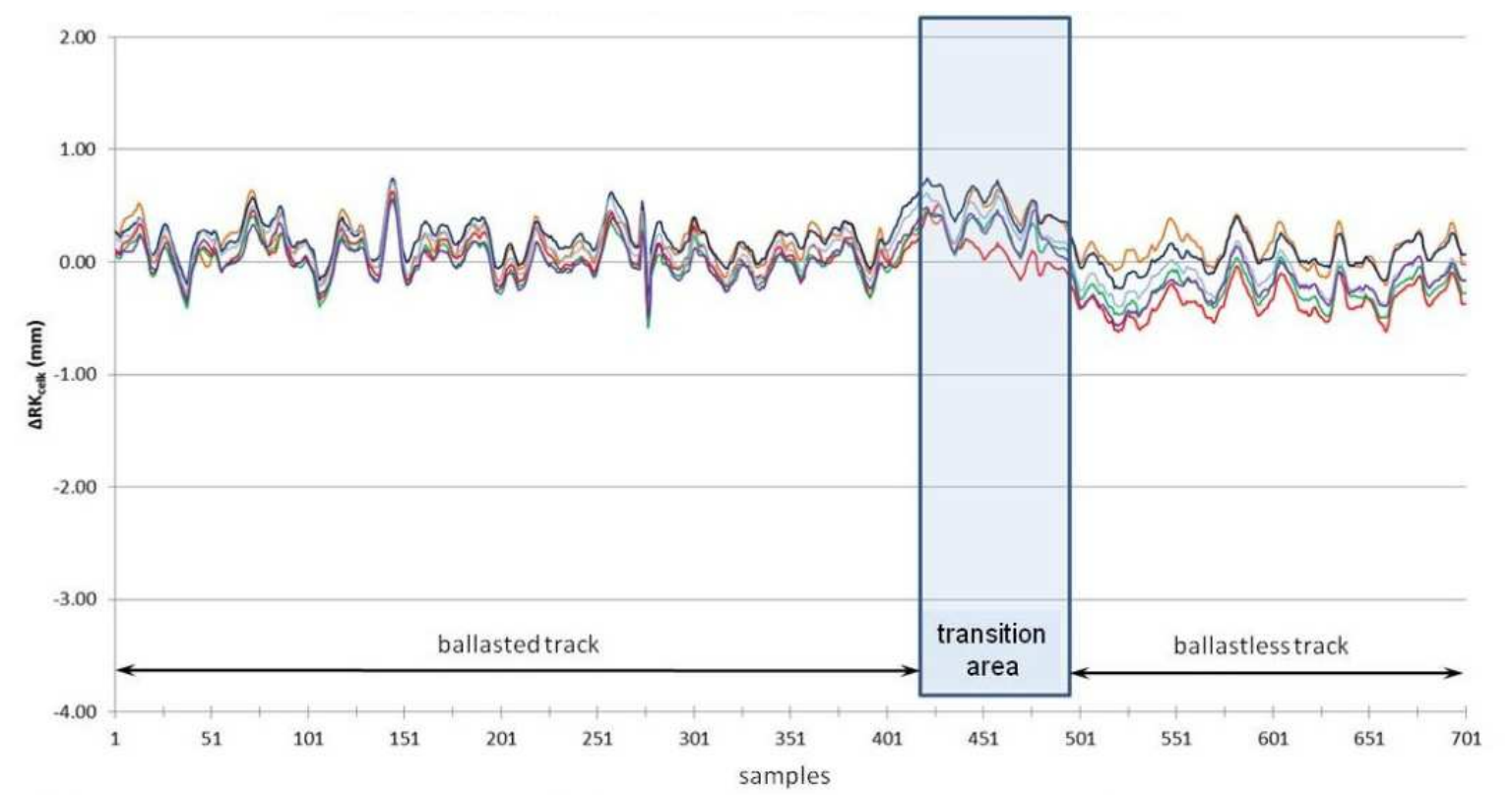

- differences between PO1 and MSO RK - differences between PO2 andMSO RK _ differences between PO3 and MSO RK _ differences between PO4 andMSORK _ differences between PO5 andMSORK _ differences between PO6 and MSO RK

Fig. 7: Gauge deviation ( $\Delta \mathrm{RK})$ - differences between measurement before putting section into operation and operational measurements - Track No. 1, Section No. 1 (southern portal).

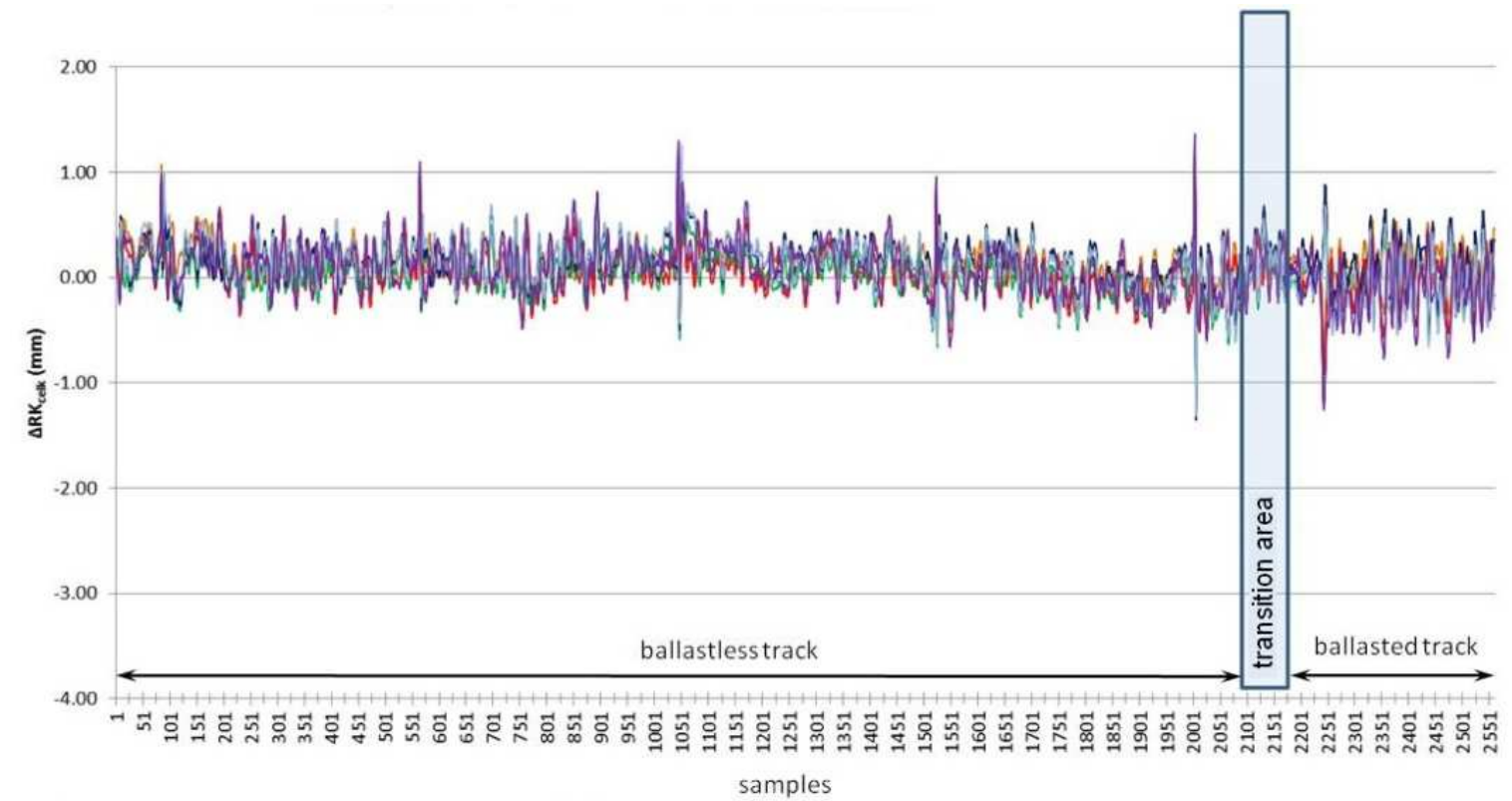

- differences between PO1 andMSORK _- differences between PO2 and MSO RK _ differences between PO3 andMSO RK

differences between PO4 and MSO RK _ differences between PO5 and MSO RK — differences between PO6 and MSO RK

Fig. 8: Gauge deviation ( $\Delta R K)$ - differences between measurement before putting section into operation and operational measurements - Track No. 1, Section No. 2 (northern portal). 


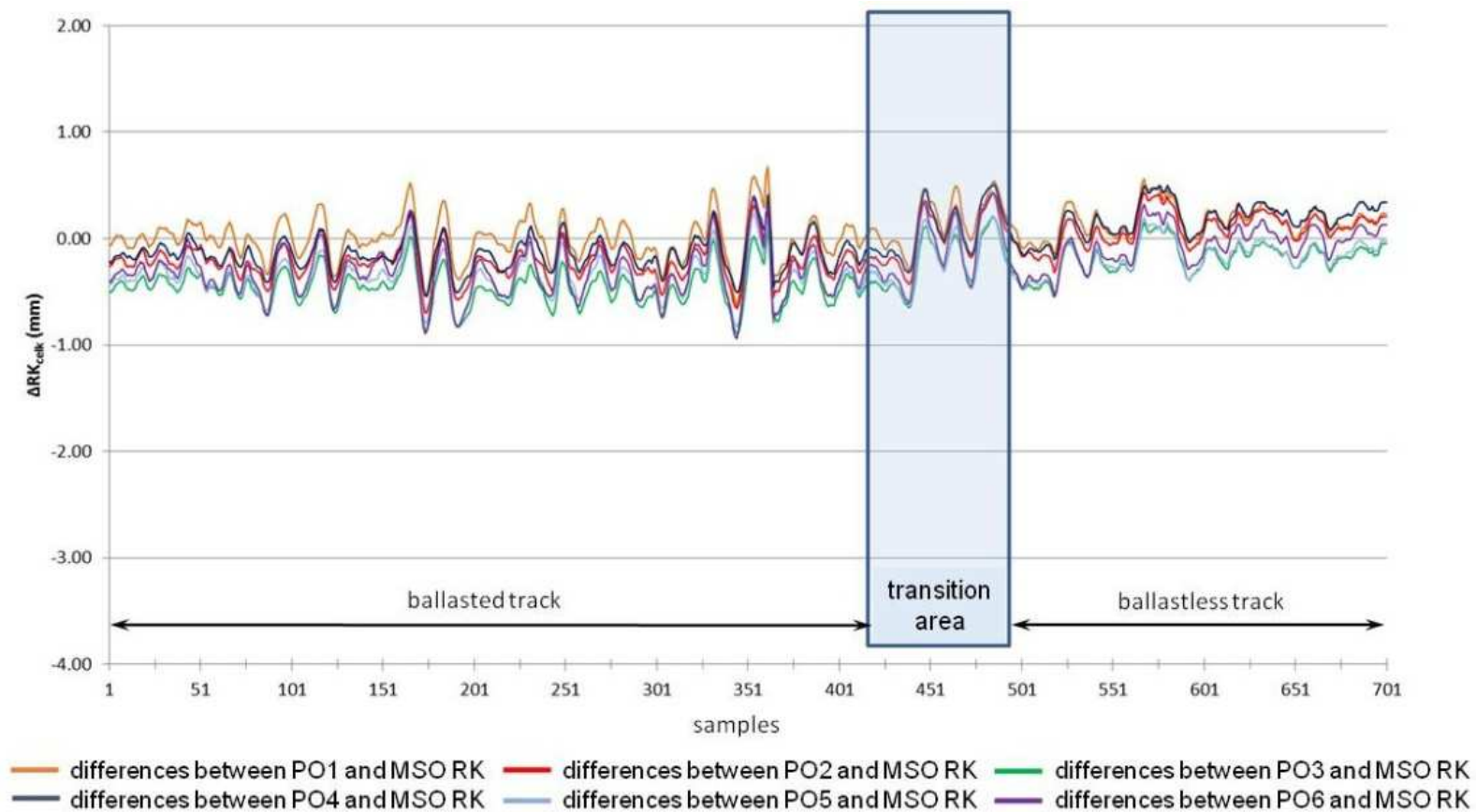

Fig. 9: Gauge deviation ( $\Delta \mathrm{RK})$ - differences between measurement before putting section into operation and operational measurements - Track No. 2, Section No. 1 (southern portal).

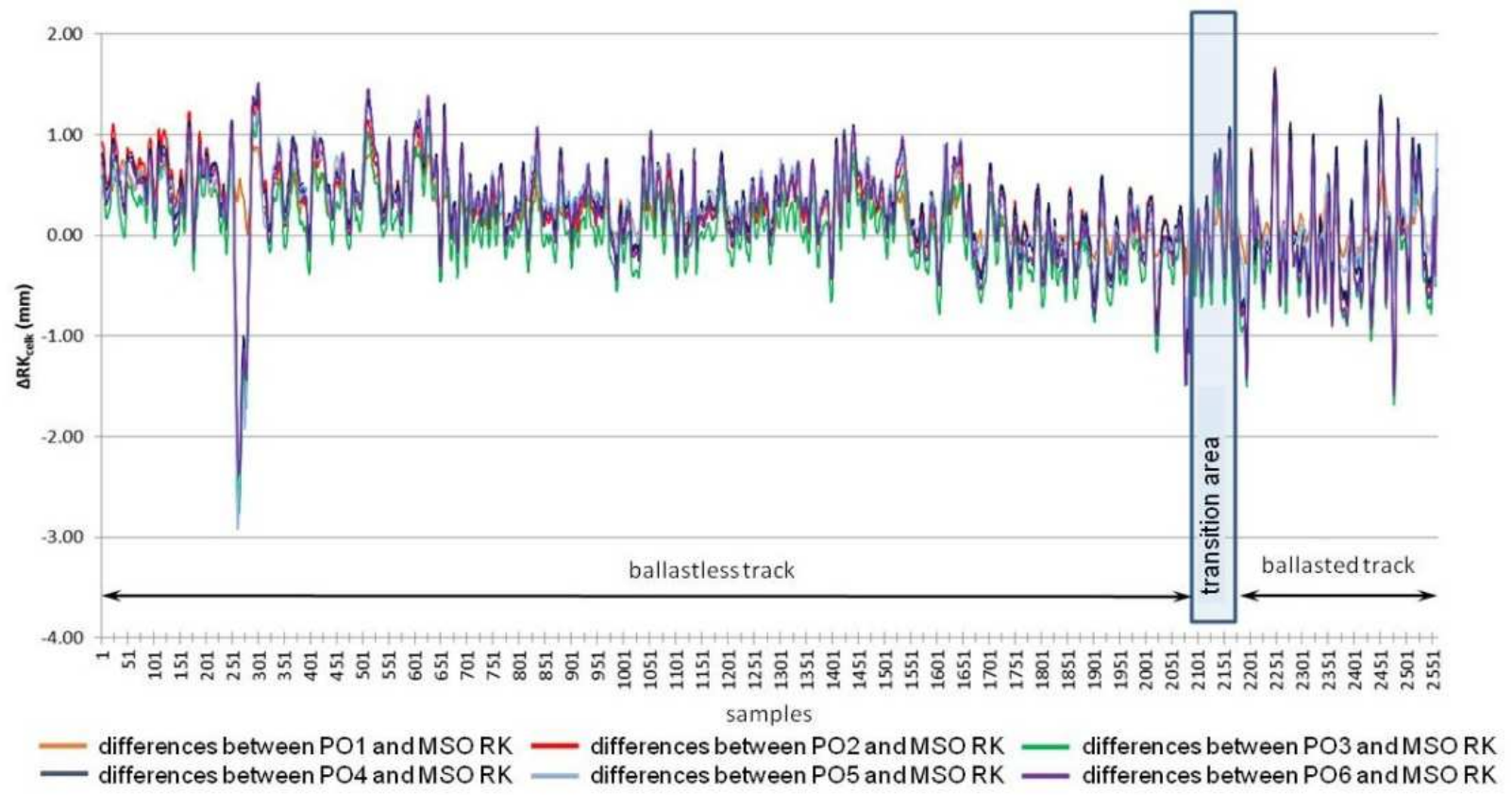

Fig. 10: Gauge deviation ( $\Delta R K)$ - differences between measurement before putting section into operation and operational measurements - Track No. 2, Section No. 2 (northern portal). 


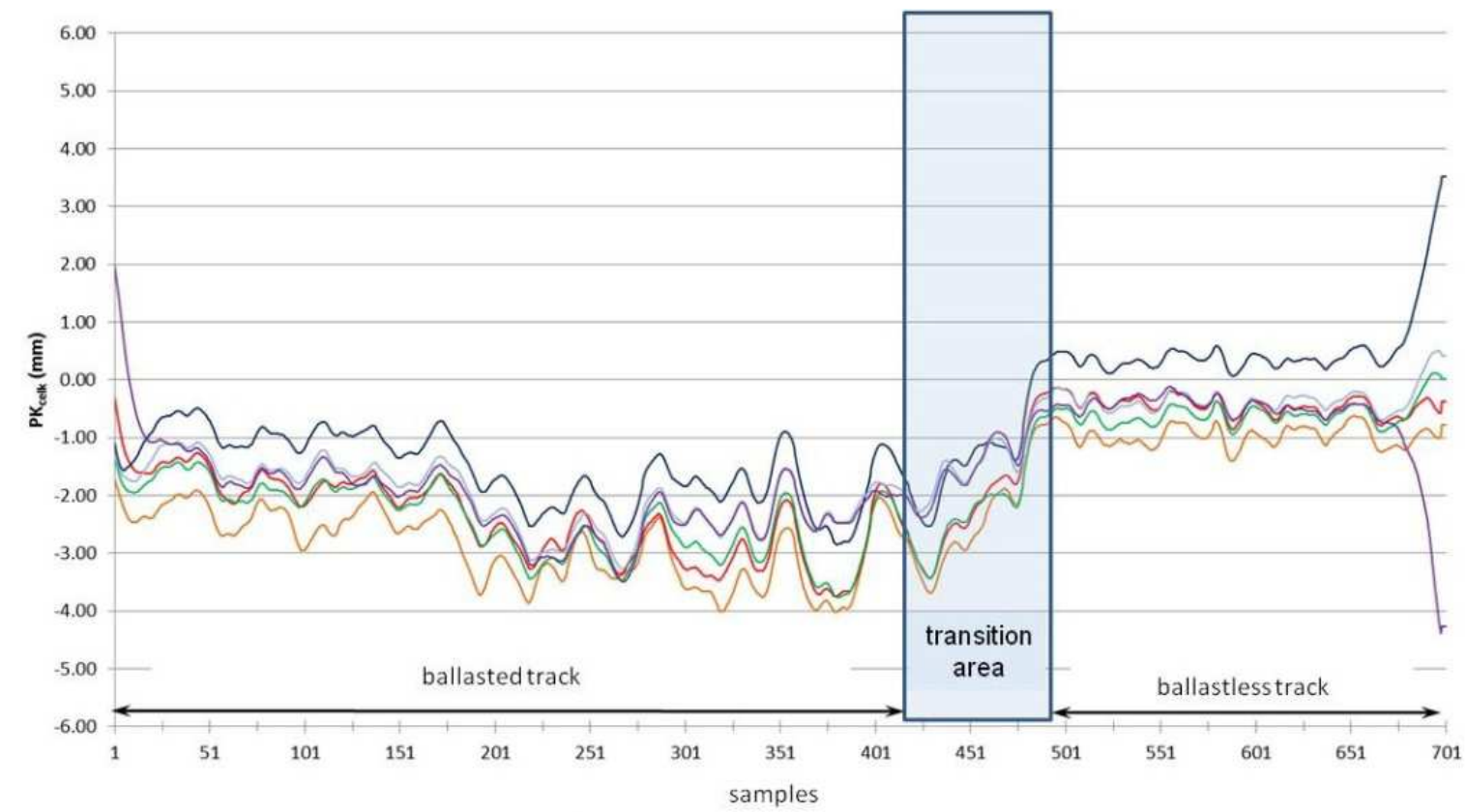

- differences between PO1 and MSO PK — differences between PO2 and MSO PK — differences between PO3 andMSO PK

_ differences between PO4 andMSOPK __ differences between PO5 andMSO PK _ differences between PO6 and MSO PK

Fig. 11: Cant (PK) - differences between measurement before putting section into operation and operational measurements - Track No. 1, Section No. 1 (southern portal).

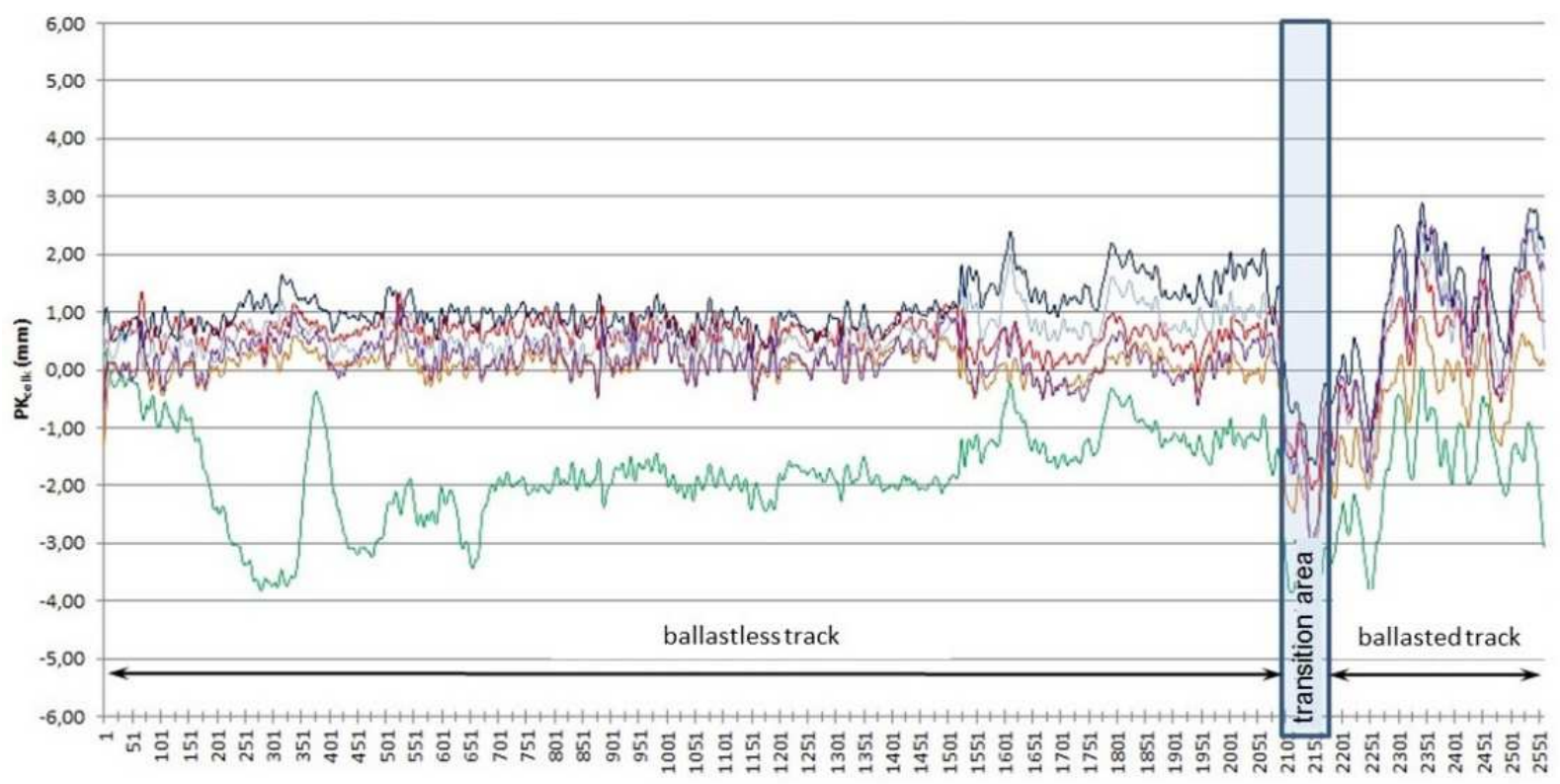

samples

differences between PO1 and MSO PK — differences between PO2 and MSO PK - differences between PO3 and MSO PK differences between PO4 and MSO PK _ differences between PO5 and MSO PK _ differences between PO6 and MSO PK

Fig. 12: Cant $(\mathrm{PK})$ - differences between measurement before putting section into operation and operational measurements - Track No. 1, Section No. 2 (northern portal). 


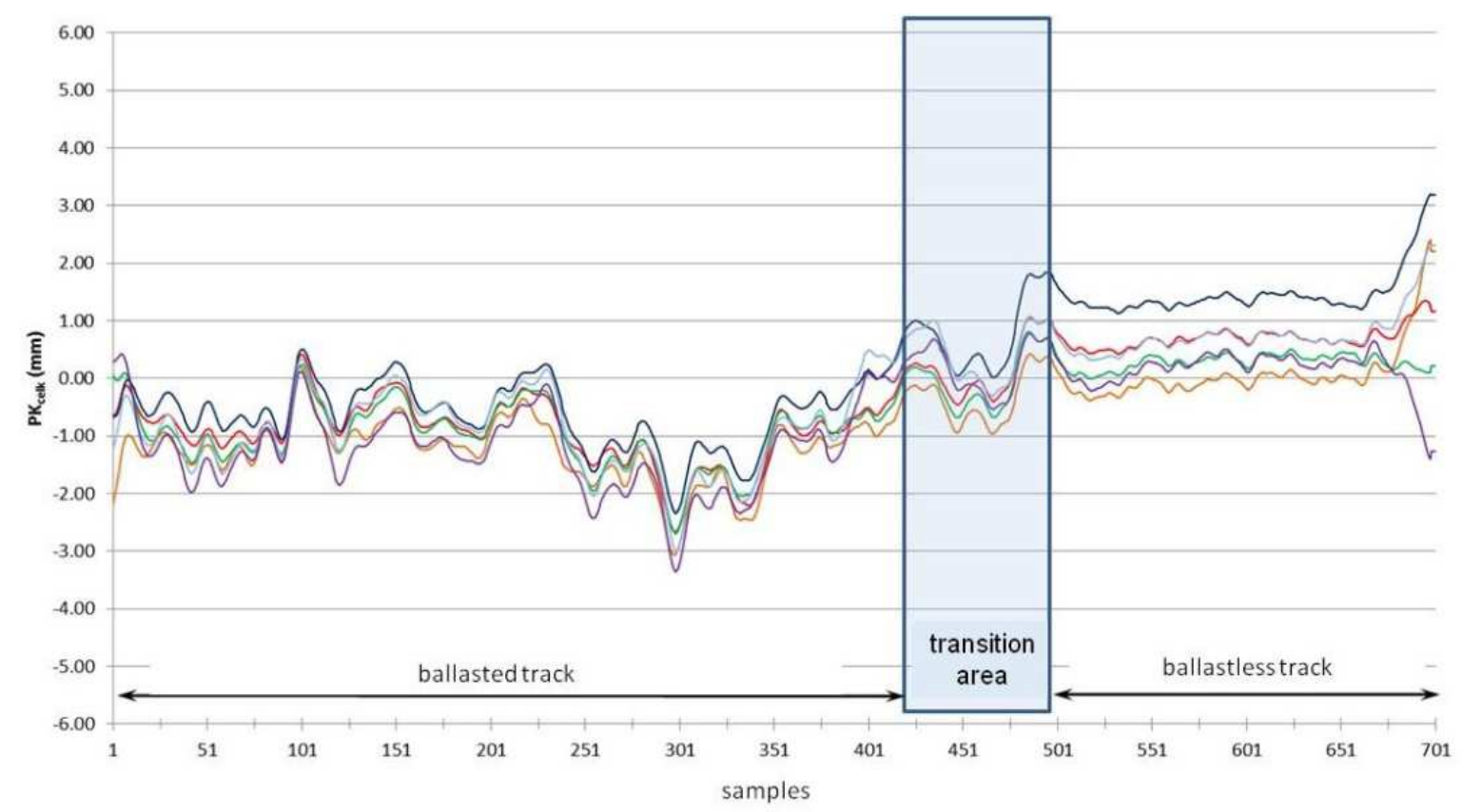

differences between PO1 and MSO PK - differences between PO2 and MSO PK - differences between PO3 and MSO PK
differences between PO4 and MSOPK - differences between PO5 and MSO PK _ differences between PO6 and MSO PK

Fig. 13: Cant (PK) - differences between measurement before putting section into operation and operational measurements - Track No. 2, Section No. 1 (southern portal).

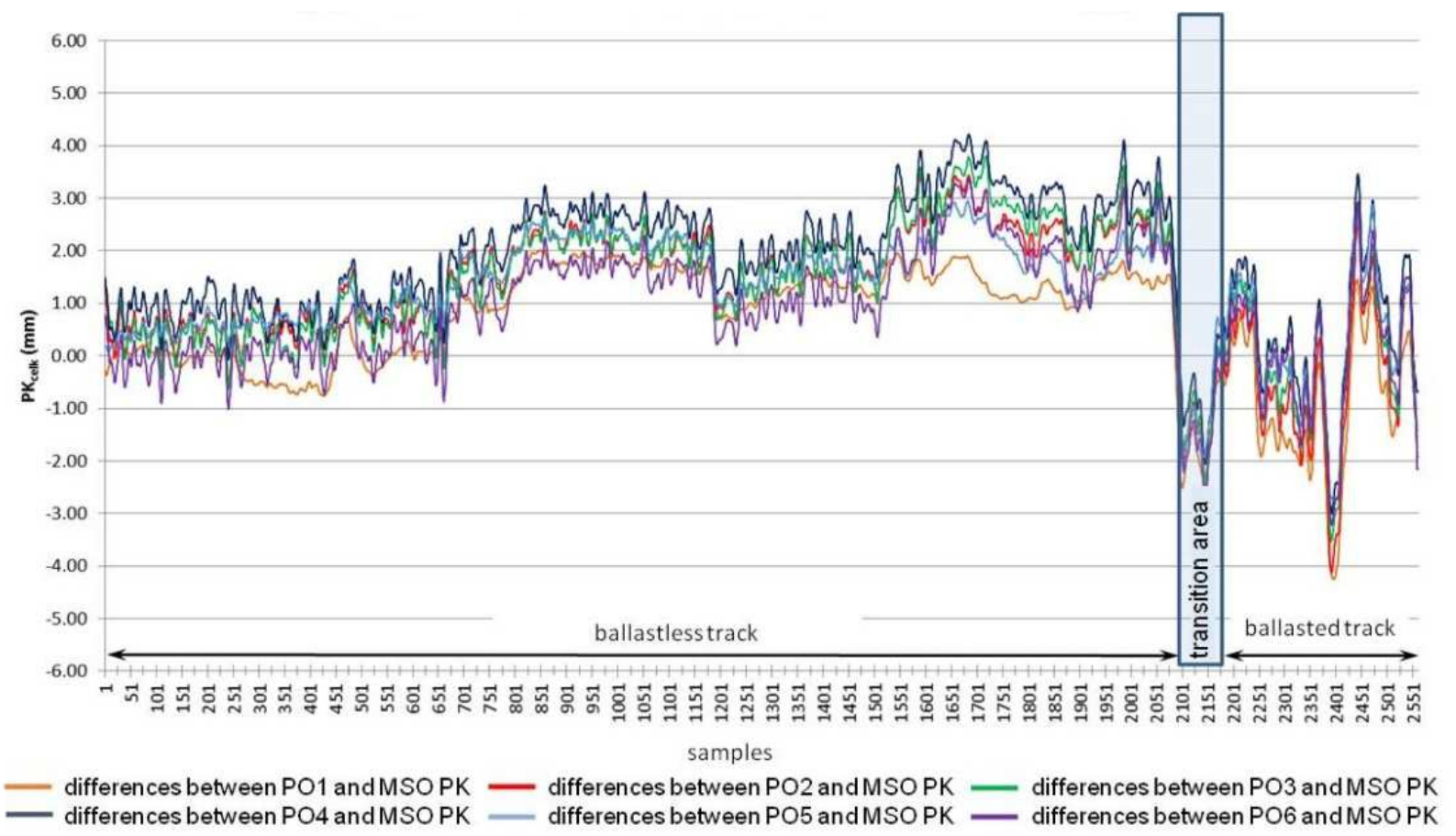

Fig. 14: Cant (PK) - differences between measurement before putting section into operation and operational measurements - Track No. 2, Section No. 2 (northern portal).

\section{Conclusions}

Section with the lowest quality shown by evaluation is section of track No. 1 in the area of southern portal, where incidence of local errors is the highest as well as the quality mark and the number of quality. Infrastructure manager carried out maintenance works at the area of southern portal, but the quality of track geometry is still decreasing. 
Significantly different from the trend of results is the third operational measurement $\mathrm{PO} 3-$ parameter $P K$ in section No. 2. At the time of measurement were rail heads in the section very dirty and this fact affected results obtained from the measuring trolley. Therefore, measurement results PO3 of parameter PK in this section are not classified to the summary assessment.

Monitoring of track alignment design and track geometry of ballastless track sections and transition areas is for infrastructure manager very significant in case of design, construction and maintenance of this kind of structures in the future.

\section{Acknowledgement}

There are partial results of the grant VEGA 1/0597/14 "Analysis of methods used to measure the unconventional railway track construction from the point of view of accuracy and reliability" in the paper.

\section{References}

[1] IŽVOLT, L. - ŠMALO, M.: Historical Development and Applications of Unconventional Structure of Railway Superstructure of the Railway Infrastructure of the Slovak Republic. In: Civil and Environmental Engineering. Volume 10, Issue 2. EDIS, University of Žilina, 2014. ISSN 13365835, p. $78-93$.

[2] ŠESTÁKOVÁ, J.: Quality of Slab Track Construction - Track Alignment Design and Track Geometry. In: Civil and Environmental Engineering. Vol. 11, Issue 1. EDIS, University of Žilina, 2014. ISSN 1336-5835, p. 2 - 9.

[3] ŠESTÁKOVÁ, J. - MEČÁR, M.: Evaluation of Track Design and Track Geometry of the Track with Unconventional Structure of Railway Superstructure. In: Proceedia Engineering. Vol. 111. XXIV. R-S-P Seminar, Theoretical Foundation of Civil Engineering (24 RSP). ISSN: 1877-7058, p. $709-716$.

[4] IŽVOLT, L. - IŽVOLTOVÁ, J. - ŠESTAKOVÁ, J.: Influence of Construction of Railway Superstructure on Railway Quality. In: Applied Mechanics and Materials. Volume 617. Trans Tech Publications, ISSN 1660-9336, p. 54 - 59.

[5] IŽVOLTOVÁ, J. - VILLIM, A. - PISCA, P.: Analysis of Height Changes of Ballast-Less Track. In: Geodézia, kartografia a geografické informačné systémy, VIII. vedecko-odborná medzinárodná konferencia - zborník príspevkov. Tatranské Matliare, SR, 17. - 19. 09. 2014. Košice : Technická univerzita, 2014. ISBN 978-80-553-1781-6.

[6] STN 736360 (1999) Track alignment design and track geometry of normal-gauge tracks, SÚTN Bratislava and Amendment 1 (2002), SÚTN Bratislava.

[7] ZSR SR 103-7 (S) Measurement and Evaluation of Track Geometry by Measuring Trolley KRAB (in Slovak). GR ZSR, 2008.

[8] Continuously measuring trolley KRAB ${ }^{\mathrm{TM}}$-Light. Available online: http://kzv.cz/Czech/krab.php

[9] IZVOLT, L. et al.: Monitoring of Sections of Non-conventional Constructions of the Railway Superstructure and the Transition Areas $-3^{\text {th }}$ and $4^{\text {th }}$ Stage. ZSR Modernization of Railway Track Nove Mesto nad Vahom - Puchov, km 100.500 to 159.100, part 24-32-01 Nove Mesto Trencianske Bohuslavice (in Slovak). Zilina, KZSTH SvF, University of Zilina, 12/2013.

[10] IZVOLT, L. et al.: Monitoring of Sections of Non-conventional Constructions of the Railway Superstructure and the Transition Areas $-5^{\text {th }}$ and $6^{\text {th }}$ Stage. ZSR Modernization of Railway Track Nove Mesto nad Vahom - Puchov, km 100.500 to 159.100, part 24-32-01 Nove Mesto Trencianske Bohuslavice (in Slovak). Zilina, KZSTH, SvF, University of Zilina, 12/2014.

[11] IZVOLT, L. et al.: Monitoring of Sections of Non-conventional Constructions of the Railway Superstructure and the Transition Areas $-7^{\text {th }}$ and $8^{\text {th }}$ Stage. ZSR Modernization of Railway Track Nove Mesto nad Vahom - Puchov, km 100.500 to 159.100, part 24-32-01 Nove Mesto Trencianske Bohuslavice (in Slovak). Zilina, KZSTH, SvF, University of Zilina, 12/2015. 